\title{
Brain Drain from Sri Lankan Universities
}

\author{
Chandra Gunawardena ${ }^{1 *}$ and Rasika Nawaratne ${ }^{2}$ \\ ${ }^{I}$ Emeritus Professor in Education, The Open University of Sri Lanka, Nawala, Sri Lanka. \\ ${ }^{2}$ Department of Secondary and Tertiary Education, Faculty of Education, The Open University of Sri Lanka, Nawala, Sri Lanka.
}

\begin{abstract}
The phenomenon of Sri Lankan university academics migrating after their postgraduate education appears to have increased over the years. Migration of academics who are among the brightest in the academic profession has a severe adverse impact on the quality of higher education. There are strong reasons for the 'Brain Drain', such as incomes and living standards in rich countries being substantially higher and research facilities and opportunities being better in developed countries. This article attempts to analyse the distribution of migrant academics and the funding used by them from 1990 to 2012, and to identify the reasons which motivate academics to resign from their substantive positions. The survey revealed that the majority of these academics had paid back their bonds. They were experienced in their specialised areas, had benefitted from postgraduate education and international research in eminent universities and clearly represented a category of academics that can definitely make a contribution to the Sri Lankan university system. They pointed out, however, that the decision to migrate was not merely an outcome of attractive prospects overseas, but also due to frustrations and difficulties encountered in changing even minor procedures, a lack of collegiality and teamwork and a lack of readiness to adapt and change in the country and the university system.
\end{abstract}

Keywords: Brain Drain, quality of university education, migrant academics, migration decisions.

\section{INTRODUCTION}

The phenomenon of Sri Lankan university academics migrating after their postgraduate education appears to have increased over the years. Especially in view of the fact that those who obtain placements, proceed for postgraduate education and succeed in completing studies being among the brightest in the academic profession, has a severe adverse impact on the quality of higher education. It is also noteworthy that the majority of these academics have proceeded for their postgraduate education using scholarships provided by the government or donor agencies as grants or loans. The impact of the loss of these academics to the country should not be underestimated, especially in the present scenario, where
Sri Lanka attempts to produce educated youth who can demonstrate competencies needed for the twenty-first century in a globalised labour market.

The steps taken to address quality issues in the academia in recent years include among others, (1) Higher Education for the Twenty-first Century, (2) Improving Relevance and Quality of Undergraduate Education Project (IRQUE) funded by the World Bank, (3) the initiatives of the University Grant Commission (UGC) in strengthening staff development activities and (4) revision of the schemes of marking related to confirmation and promotion of academic staff to make them more stringent. The IRQUE project is specifically expected to benefit the academic staff of universities by: (i) providing them with opportunities for career development through postgraduate degree programmes, exchange fellowships and study visits; (ii) improving their working conditions through investments in Information and Communications Technology, equipment and academic literature; and (iii) enhancing professional opportunities through consulting and business linkages with industries.

The National Centre for Advanced Studies in Humanities and Social Sciences (NCAS) was set up under the UGC with the declared purpose of expanding opportunities for academics from Humanities and Social Sciences to improve their research capabilities and postgraduate qualifications and has provided overseas scholarships to a large number of academics. Thus from 2006 to 2013 NCAS has granted financial support for 325 academics to pursue their postgraduate studies, 102 of whom have completed their Ph.D or M.Phil degrees (NCAS, 2014). The UGC as well as individual universities also sponsor research and training for academics.

Examination of data on university academic staff (UGC, 2013) indicates that the percentage of professors 
and associate professors in the 15 universities add up to 15 per cent of the total academic staff. It also clearly indicates the disparities among universities, with the University of Colombo, University of Kelaniya, and University of Peradeniya having more than 20 per cent, University of Sri Jayewardenepura, University of Moratuwa and University of Ruhuna having between 15-19 per cent while the University of Visual and Performing Arts has 10 per cent of its academic staff in the professorial grades. University of Jaffna, Open University and the University of Wayamba had between 5-9 per cent, while Eastern University, Rajarata University and Uwa-Wellassa University had less than 5 per cent of their academic staff in the professorial grades. South-Eastern University had no professors or associate professors.

The quality of academic staff directly influences the quality of university teaching-learning, research and their contribution to the development of society and thereby the quality of the products of the university system. The exposure to world-ranked universities with access to specialised training and state-of-the art technology and advances in academic disciplines is a pre-requisite that motivates the government and universities to nominate and support postgraduate education of university academic staff for overseas studies. Such objectives can only be achieved if the academics who succeed in completing their overseas education through scholarships or fellowships return to the country and contribute to strengthen university education, motivate and encourage junior staff to engage in research and perform as role models.

World Bank (2009) pointed out that skilled and qualified academic staff is a prerequisite for a successful quality strategy.

"One objective in many countries is to ensure that as large a proportion of academic staff as possible have a doctorate since this is the best form of academic training... One of the issues which concerns universities in Sri Lanka is the large number of young staff who go overseas for their $\mathrm{PhD}$ studies and fail to return preferring to take a position in a foreign country. There are strong reasons for this 'Brain Drain'. In particular, incomes and living standards in rich countries are substantially higher than in Sri Lanka. Also research facilities and opportunities are considerably better in developed countries. Strategies to counter the brain drain and attract young PhDs should include improving research opportunities and increasing private-public research linkages.” (World Bank, 2009)
World Bank (2011) identified Sri Lanka as one among the top five emigrating countries of tertiaryeducated persons in South Asia. The stock of emigrants as a percentage of the population in 2005 was estimated as 4.5. Emigration of tertiary-educated from Sri Lanka was the highest (with 27.5\%), followed by Afghanistan (13.2\%), Pakistan (9.2\%), Bangladesh (4.7\%) and India (4.2\%), among the South Asian countries. The number of physicians who had emigrated from Sri Lanka in 2005 was 1,663 or $17.4 \%$ of the physicians trained in the country.

It is against the above background, that concern has been expressed regarding the Brain Drain of university academics from Sri Lanka. The interest taken by the governments to develop the university academics is especially to prevent the emergence of 'leaderless' or 'headless' professions in this country.

The current study aims to

1) Analyse the distribution of migrant academics and the funding allocated to them by universities from 1990 to 2012,

2) Identify the reasons which motivate academics to resign from their substantive positions, and

3) To suggest strategies to address the issue of Brain Drain in Sri Lankan higher education.

The study will alert the policy makers to consider adopting strategies that could reduce Brain Drain from universities in the future.

\section{REVIEW OF LITERATURE}

The term "Brain Drain" was first popularised in the 1950s with reference to the immigration to the United States of first-rank scientists from countries such as the United Kingdom, Canada and the former Soviet Union. It is now used in a more general sense to designate the international transfer of human capital (people with higher education) from developing to developed countries (Rapport, 2002).

Concepts such as Brain Drain, Brain Waste and Brain Exchange (Salt, 1983; Bernstein and Shuval, 1998) occur for the most part in research papers whose main purpose is to analyse the decision of a highly educated person to emigrate and the effect of that decision on his or her country of origin. Yet, in some countries people may emigrate for reasons unconnected with their qualifications, as is shown from the "ethnic" migrations that took place within the former Soviet Union 
(Rhode, 1993) or the exodus of Jewish academics and professionals from Eastern Europe to Israel (Bernstein and Shuval, 1995).

The main conclusion drawn from some studies is that for any given developing country, the optimal migration rate of its highly educated population is likely to be positive. This also suggests that rich countries should not necessarily see themselves as free riding on poor countries' educational efforts. The difficulty is then to design quality-selective immigration policies that would address the differentiated effects of the Brain Drain across origin countries without distorting too much the whole immigration system. This could be achieved, at least partly, by designing specific incentives to return migrants to those countries most negatively affected by the Brain Drain and to promote international cooperation aimed at furthering Brain Circulation.

Brain Drain has increased dramatically since the 1970 s due partly to the introduction of "qualityselective" immigration policies in most OECD countries (Point systems in Australia and Canada in the 1980s, U.S. Immigration Act of 1990, etc.). For the most part, however, the migration of skilled labor is driven by the general trend towards economic globalisation, which strengthens the natural tendency for human capital to agglomerate where it is already abundant.

Papademetriou and Yale-Loehr (1996) introduced the concept of 'priority workers' which is more useful from the host country's point of view, because it focuses on the part played by the host country which obtains benefits from highly-qualified expatriates whose skills are regarded as advantageous to the national economy.

One idea that gained much currency was that highly-qualified people were moving to emerging economies where they made their skills available, e.g. South-East Asia and Poland. Skilled immigrants and family members accounted for over 50 per cent of those migrating to Australia, Canada and New Zealand (Global Commission for International Migration, 2005).

The economic development of some countries, especially Korea, Taiwan and South-East Asia (Teng, 1994; Skeldon, 1992), has enabled many of their researchers who had gone abroad to come home again and their return has helped accelerate economic development.

In recent years, interest in Brain Drain has revived. The studies however, have tended to focus mainly on regions such as Latin America and India (CastonosLomnitz, 1998; Iredale, 1999; Awasthi and Chandra,
1994; Robinson and Carey, 2000) where the state of scientific and technological progress is advanced. Highlyqualified migration can also be looked at from a third perspective, that of the employer. Employers, especially trans-national corporations, are becoming increasingly involved in and responsible for the migration of qualified personnel (Salt, 1997).

Migration of skilled persons from the developing to the developed world has been termed both as a Brain Drain and a Brain Gain. As Lovell (2001) points out, skilled emigration from developing countries can stimulate economic growth in such countries, but when the outflows are significant, a Brain Drain is created. He points out that skilled emigration triggers multiple impacts. Among them, the prominent are,

1) Skilled emigration reduces the number of educated workers who are critical to a developing country's productivity and economic growth,

2) Returnee migrants, bring back their skills and work experience from abroad boosting productivity,

3) Expatriates who remain abroad contribute money via worker remittances,

4) Their transfer of knowledge or technology to developing countries can increase productivity and economic development.

Among the indirect effects of migration are

1) The possibility of emigration for higher wages to encourage persons to pursue education and increase domestic enrollments.

2) Average workforce skill is thereby increased and economic growth stimulated - there may be an "optimal level" of skilled emigration.

3) Finally, "Brain Exchanges" between countries characterise all advanced economies, forming one component of the flow of goods and information in a globalising economy.

On the other hand, it is also evident that if these favourable developments are to take place, the country of origin must contain a sufficiently large nucleus of scientists and be able to retain at least a minimal scientific and economic potential before their expatriate scientists can contribute to its further development or be enticed back home. In the absence of this, not only will the scientific and technical system of the country continue to 
deteriorate owing to the loss of trained human resources, but also all capable students will inevitably be forced to specialise abroad and remain there forever (Iredale, 1999; Castanoz-Lomnitz, 1998).

It is not proven that the migrants themselves gain any substantial advantage from their diaspora. For example, Australia has received an increasing number of immigrants from non-English-speaking countries, including a record number of qualified workers. But after a decade of receiving skilled foreigners, clear cases of indirect and direct discrimination can be found, as shown in studies by Hawthorne (1997). One study, investigating indirect discrimination, showed how the federal government of Australia has increasingly bowed to the lobbying of the medical association to limit the influx and recognition of immigrant doctors through the imposition of an unjustified requirement for a perfect command of the English language. The second case study looks at a sample of elite expatriates chosen from the qualified immigrants to Australia. It looked at foreign engineers of an age well suited for integration into the Australian workforce, whose command of English was good, and who had excellent previous experience before arriving in the country. The study showed the existence of clearcut discrimination in favour of immigrants whose mother tongue was English or who were of European origin to the detriment of immigrants of Asian and Middle Eastern origin. Furthermore, some researchers have highlighted the disproportionate presence of highly qualified immigrants in a limited number of "global cities". The primary reason for this concentration is, simply, that such cities have a greater availability of specialist work for qualified expatriates and the higher salaries that go with it. Even if acceptance of foreigners is far greater in these environments than elsewhere, it cannot be ruled out that a massive inflow of well-qualified foreigners into a restricted geographical area could eventually give rise to problems of rivalry and even ethnic friction. There is some evidence that the practice of almost automatically accepting immigration applications from highly qualified foreign workers is now being called into question. Misgivings have been expressed in the United States, Canada and Australia regarding the efficacy of "emigration market" policies designed to draw in highlyqualified workers. The impact of this sort of immigration on the local skilled population is now a matter of discussion (Papademetriou and Yale-Loehr, 1996).

Mountford (1997) emphasised the positive schooling effects of introducing a positive probability of migration. In this seminal contribution the possibility of temporary migration was also mentioned as an alternative to permanent migration for producing positive schooling incentives. At least in theory, access to international labor markets, where returns to human capital are higher than domestic returns, may induce people in less developed countries to pursue higher education. Such an incentive mechanism, combined with the uncertainty of migration (due to immigration laws and procedures), may result in greater acquisition of education by people who end up staying in the country.

Chau and Stark (1999) added the possibility of asymmetric information with respect to workers' quality and showed that migration would be followed by the return of migrants at both ends of the skill spectrum, which could be welfare enhancing for the country of origin.

Beine et al. (2001) point out that though education has been considered as a major determinant of long-term growth, Brain Drain is detrimental for the country of emigration. They quote studies on the negative impact of the Brain Drain stressed in the New Growth literature (Miyagiwa, 1991; Haque and Kim, 1995; Galor and Tsiddon, 1997) that underline the positive impact of migrations on human capital formation, but which conclude that there is a detrimental growth effect of Brain Drain. They argue the need to distinguish between the two effects of the Brain Drain on growth: an ex ante brain effect migration prospects foster investments in education because of higher returns to education abroad, and an ex post drain effect, some, if not all educated agents actually migrate. The case for a Beneficial Brain Drain (BBD) emerges when the first effect dominates, i.e., when the average level of human capital is higher in the economy opened to migrations than in the economy without migration possibilities. They tested out a model that focused on the impact of migrations on human capital formation and growth in the source country of migrants with a sample of 37 developing countries and found that the first impact, potentially beneficial, accounts for the fact that migration opportunities foster investments in education since it is awarded a higher expected return when the economy is opened to migrations; which they called the Brain Effect. They have shown that BBD is likely to occur in two cases: when the economy is originally closed to an underdevelopment trap and migration probabilities are not too high, and when the economy already exhibits a relatively high growth performance and that migration probabilities take intermediate values. At the empirical level, they have provided some evidence showing that the possibility of a BBD is perhaps more than a theoretical curiosity, mainly because migration prospects seem to play a significant role in education decisions. 
Adams (2003) points out the key role of education in migration. Thus about $67 \%$ of all immigrants to US and $88 \%$ to OECD (of whom $69 \%$ are tertiary-educated) are shown to have a secondary or higher education. Countries in South Asia are shown as producing a larger share of the tertiary-educated migrants. Migration to OECD is shown as causing a Brain Drain in 13 countries of which in five countries, more than $10 \%$ of those with a tertiary education have migrated, with Sri Lanka having a $16.5 \%$ of such migration.

Haque (2007) quoting National Science Foundation, USA, states that USA relies heavily on imported scientists. $23 \%$ of those having doctorates are not USA born and that $50 \%$ of those who complete their Ph.Ds. remain in USA.

Haque (2007) describes the 'Knowledge Pyramid", which frames every profession in a country. The general practitioners make up the base of the pyramid. As one climbs up the pyramid, professionals with a deeper knowledge of what their professions are needed. They must know their subject in greater depth and have the ability to keep up with what is happening in their professions. Unless there is a larger number of researchers/advanced academics at the top of the pyramid, the ability of the entire profession to keep pace with the frontiers of the profession will be seriously impeded. With the best of professionals migrating, many countries develop professions that are 'leaderless or 'headless'... it is obvious that for developing research and knowledge capacity, a country must retain or obtain brains.

Recent case studies emphasise that returnees have been important sources of entrepreneurship (Constant and Massey, 2002; McCormick and Wahba, 2004), particularly for start-ups in high tech sectors in countries such as India (Commander et al., 2008) and in the Hsinchu Science Park in Taipei (Luo and Wang, 2004).

Dustmann and Weiss (2007) use UK data to show that the tendency of migrants to return to their country of origin is much stronger among workers in highly skilled occupations and that the migrants' return occurs mostly within ten years of their arrival. Similarly, Gundel and Peters (2008), using data on migrants to Germany, show a much higher return rate for the highly educated compared with the less educated.

Schiff and Wang (2008), examining the relationship between Brain Drain and productivity growth in small states, indicate that small developing states experience a very high rate of Brain Drain (43.2\%). Their findings imply that productivity growth in small countries is more sensitive than in large ones to changes in the Brain
Drain and that Brain Drain has a negative effect on productivity growth and that the impact of Brain Drain for all developing countries (7.4\%) is estimated as twice that of high income countries (3.5\%).

Mayr and Peri (2009) developed a simple, tractable overlapping generations model that provides a rationale for return migration and predicts who will migrate and who returns among agents with heterogeneous abilities. The model incorporated the interaction between the migration decision and schooling: the possibility of migrating, albeit temporarily, to a country with high returns to skills produces positive schooling incentive effects. They found that the possibility of temporary migration to a country with high returns to schooling produces most of the same positive incentive effects as the possibility of permanent migration. First, the individuals who plan to migrate and return invest more in schooling since their return to schooling, while abroad and also after returning, are higher. Their model showed that a key parameter in determining the selection of return migrants and their level of schooling is the wage "premium" that they obtain upon return, relative to workers with similar characteristics who never migrated. They call this the "return premium". Such a premium determines the share of emigrants who return as well as their selection. They concluded that, as Western Europe pays a higher return to skill relative to Eastern Europe, the possibility of migration induces potential temporary and permanent migrants in the East to invest more in human capital. This investment, plus the fact that some migrants return while other potential migrants end up staying in the East, has a positive effect on average schooling that more than offsets the negative effect of Brain Drain.

A central challenge for developing countries is to engage appropriately in the exchange of skills taking place in the global labor market. Ready examples exist of developing countries engaging in and benefiting from the international migration for the trade in services.

\section{METHODOLOGY}

The study consisted of two phases: analysis of recorded information from individual universities regarding the academics who had migrated and a survey of those who had migrated overseas. The study focused only on those who had migrated after 1990.

The Vice-Chancellors of all the universities were sent a letter, in which the objectives of the study were explained, requesting for information on academic staff that resigned after 1990 assuring them that the information supplied will be treated with absolute confidentiality. 
The information requested is given in the Appendix. It was possible to obtain the above information from some of the universities, though after several requests. One of the Vice Chancellors responded saying that the information could not be given as the request had not been approved by the Research Ethics Committee while four others informed that the request should be sent through the Vice- Chancellor of the particular University to which the researcher was affiliated, which was duly done. The information requested from Universities in August 2012, was received from the University of Colombo, University of Kelaniya and Open University in November 2012, University of Sri Jayewardenepura and University of Wayamba in December 2012, University of Uwa Wellasa, University of Moratuwa, University of Peradeniya, University of Sabaragamuwa and South-Eastern University in 2013. Notable among non-responding universities were the University of Jaffna and Eastern University, from which the number of migrant academics could have been higher. Some of the universities stated that email addresses which were needed for the second phase of the survey could not be released.

A questionnaire was sent to the 43 academics whose email addresses were available assuring them that the information would be treated confidentially. The recipients were requested to furnish email addresses of other Sri Lankan academics if they had access to them and a positive response was received from one who sent several addresses. Fifteen of the emails were returned undelivered. Only eleven had responded even after four reminders. As the response rate was very low, an online survey was designed so that the respondents could provide information without revealing their identity. A similar request to respond to the online survey was made to academics and scientists who were in the National Science Foundation Network. The total number of academics who had responded (when three who had resigned prior to 1990 were left out) was 27.

The analysis of the information received from the universities and the small number of respondents is presented in this paper. This study employs descriptive statistics such as percentages and means and content analysis for the analysis of information received from academics, especially as excerpts from respondents' responses would be qualitative.

The major limitations of the study were the reluctance of some universities to provide requested data, the difficulty of obtaining email addresses and the low response rate of the university academics who had migrated. The responses given by those who responded, however, provide useful insights on the reasons for migration and the misgivings some express on the decision taken.

The authors believe that the vibrant responses received from the academics compensate for the small number of those who responded.

\section{ANALYSIS OF INFORMATION OBTAINED FROM UNIVERSITIES}

Table 1 shows that the highest number of academics had migrated from the University of Sri Jayewardenepura (53), followed by the University of Peradeniya (45), University of Kelaniya (41) and the University of Moratuwa (26). Faculty-wise the highest number had resigned from the Faculties of Science (74), followed by Management (43), Engineering (37) and Medicine (32), the most prestigious among university Faculties.

Table 2 indicates that the total amount spent on postgraduate education of 181 academics amounted to more than Rs. $230 \mathrm{~m}$ and a mean of Rs. $1,298,058$. What is relevant to note here is that more than the financial loss, the effort taken to improve the quality of higher education would not have borne fruit due to the emigration of the academics. The highest mean value spent on financial support to the academics had been to those of the University of Sabaragamuwa $(4,934,891)$, followed by the University of Sri Jayewardenepura $(4,176,663)$, the Open University $(3,083,485)$ and Universities of Moratuwa $(2,474,376)$ and Colombo $(2,067,834)$.

It is noteworthy that the number of migrated academics varied by Faculty. Thus the highest number had been from Science (44), followed by Medicine (25), Arts/ HSS (16) and Engineering (12). Review of the Quality Assurance Agency in the recent evaluations indicated that the highest percentages of A's in the Subject Reviews had been received by the Departments of Engineering (79.8), Science-related (56.6), Medical-related (49.4), Management-related (47.4) and Agriculture-related (47.1) (Gunawardena, 2015). Thus, these Faculties are seen as being of good quality and the graduates from these Faculties have the highest employability. The other Faculties had very few migrant academics.

Table 3 gives requested data for only 107 academics from six disciplines and for 3 academics whose disciplines are not given. The total amount is given as Rs. 225,952,301 and the mean amount per academic is estimated as Rs. 2,054,111 but with significant variations among disciplines. The total amounts vary from Rs. 56,683, 510 for Medicine, Rs. 40,327,984 for Engineering to Rs. 36,941,057 for Arts/ Humanities and Social Sciences (HSS), Rs. 36,322,910 for Science and 
Table 1: No. of migrated academics by Faculty and University, 1990-2012

\begin{tabular}{|c|c|c|c|c|c|c|c|c|c|c|c|}
\hline \multirow[b]{2}{*}{ Faculty } & \multicolumn{11}{|c|}{ Universities } \\
\hline & UOP & UOC & UOK & USJP & UOM & OUSL & UWASL & WUSL & SUSL & SEUSL & Total \\
\hline Science & 12 & 7 & 13 & 16 & & 3 & 12 & 5 & 4 & 2 & 74 \\
\hline Medicine & 6 & & 15 & 11 & & & & -- & & & 32 \\
\hline Arts/HSS & $11^{* *}$ & 6 & 5 & & & 2 & & & 01 & 2 & 27 \\
\hline Engineering & 14 & & & & 19 & 4 & & & & & 37 \\
\hline Law * & & 3 & & & & 1 & & & & & 4 \\
\hline $\begin{array}{l}\text { Agriculture \& } \\
\text { related }\end{array}$ & & & & & & & & 3 & 3 & & 6 \\
\hline Architecture & & & & & 3 & & & & & & 3 \\
\hline IT & & & & & 1 & & & & & & 1 \\
\hline Management ${ }^{*}$ & & 5 & 5 & 26 & & 1 & 3 & 3 & & & 43 \\
\hline $\begin{array}{l}\text { Aquaculture \& } \\
\text { livestock, nutrition }\end{array}$ & & & & & & & & 6 & 4 & & 10 \\
\hline $\begin{array}{l}\text { Animal Science \& } \\
\text { Export Agriculture/ } \\
\text { Food Science }\end{array}$ & & & & & & & 4 & & 2 & & 6 \\
\hline Other ${ }^{* * *}$ & 2 & & 3 & & 3 & & & & & & 8 \\
\hline Total & 45 & 21 & 41 & 53 & 26 & 11 & 19 & 17 & 14 & 4 & 251 \\
\hline
\end{tabular}

Source: Respondent Universities

"In OUSL Education, Management and Law included in HSS, ${ }^{* *}$ Education included in Arts in UOP,

${ }^{* * *}$ Those whose disciplines had not been given.

Table 2: No. of migrated academics and bond amounts by University, 1990-2012

\begin{tabular}{lrrr}
\hline University & No. of academics migrated and bonded (*) & Bond values (Rs.) & $\begin{array}{r}\text { Mean value per } \\
\text { academic (Rs.) }\end{array}$ \\
\hline Colombo & $20(20)$ & $41,356,689$ & $2,067,834$ \\
Kelaniya & $37(37)$ & $49,833,978$ & $1,346,864$ \\
Open University & $11(11)$ & $33,918,338$ & $3,083,485$ \\
Moratuwa & $26(11)$ & $27,217,806$ & $2,474,376$ \\
Sri Jayewardenepura & $26(26)$ & $108,593,238$ & $4,176,663$ \\
Peradeniya & $45(45)$ & $\mathrm{NA}$ & $\mathrm{NA}$ \\
Wayamba & $17(1)$ & 107,298 & 107,298 \\
Uwa-Wellassa & $20(20)$ & $\mathrm{NA}$ & $\mathrm{NA}$ \\
Sabaragamuwa & $04(04)$ & $19,739,565$ & $6,934,891$ \\
South-Eastern & $14(6)$ & $4,015,599$ & 669,266 \\
$\begin{array}{l}\text { Total no. of academics } \\
\text { who had migrated - 10 }\end{array}$ & 220 & & $1,298,058$ \\
Universities & & & \\
No. of academics for \\
whom bond information \\
is available- All 10
\end{tabular}

*The numbers of academics for whom bonded amounts are available is given within brackets. 
Table 3: Migrant academics by Faculty and bond values, 1990-2012

\begin{tabular}{lrrr}
\hline Faculty & No. of academics bonded & Bond value (Total) (Rs.) & $\begin{array}{r}\text { Bond value } \\
\text { (Mean rupees per } \\
\text { academic) }\end{array}$ \\
\hline Science & 44 & $36,322,910$ & $825,520$. \\
Medicine & 25 & $56,683,510$ & $2,267,340$ \\
Arts/HSS & 16 & $36,941,057$ & $2,308,816$ \\
Engineering & 12 & $40,327,984$ & $3,360,665$ \\
Law & 03 & $9,397,918$ & $3.132,639$ \\
Architecture & 01 & 865,610 & 865,610 \\
Food Science Technology & 01 & $4,343,360$ & $4,343,360$ \\
Agriculture & 02 & $27,026,540$ & $13,513,270$ \\
Livestock Production & 03 & $8,369,658$ & $2,789,886$ \\
Faculty not stated & 03 & $1,673,754$ & 557,918 \\
Total & 110 & $225,952,301$ & $2,054,111$ \\
\hline
\end{tabular}

Some Universities had not given information on bond values

Rs. 27,026,540 for Agriculture. These amounts appear to differ from the amounts that are normally considered as the expenditure for each of the above disciplines, but it has to be noted that information as to whether the postgraduate programmes had been followed locally or overseas, and the ranking of universities which can be linked to the programme fees are not indicated here. When mean values are considered, the highest amounts have been spent on the academics from Agriculture (Rs. 13,513,270), Rs. 4,343,360 for Livestock Technology, Rs. 3,360,665 on Engineering and Rs. 3.132,639 on Law. What is more pertinent, as was pointed out earlier is that a higher number had migrated from the disciplines (Science, Medicine and Engineering) which are considered as the most relevant for Sri Lanka to improve her status as a knowledge economy. In Arts/Humanities and Social Sciences the number was 12 , which probably indicates the interest taken by the NCAS to support academics in these disciplines, even though some of them had not returned to contribute to the country.

This information has its limitations in that some of the universities had not provided information and because the information on academics who had proceeded for their postgraduate education without being bonded to the Sri Lankan universities are not included in the table.

\section{ANALYSIS OF RESPONSES FROM ACADEMICS WHO HAD MIGRATED}

In order to stem the outflow of academics, what is important is to investigate the reasons for migration from those who migrated.
The academics who responded to the survey questionnaire were from the Open University (5) and the Universities of Peradeniya (3), Moratuwa (3), Sri Jayewardenepura (2), Wayamba (1) and Colombo (1). Twelve others stated they were unwilling to declare the names of Universities and Departments.

These academics had worked in the Departments of Electrical Engineering (2), Botany (1), Business Administration (1), Chemistry (1), Chemical Engineering (1), Crop Sciences (1), Electronics and Telecommunication Engineering (1), Food Science and Technology (1), Language Studies (1), Legal Studies (1), Management Studies (1), Mechanical Engineering (1), Physics (1) and Social Studies (1).

One of them had joined as an Assistant Registrar in 1982, another as the Electronics Engineer in 1992 and thirteen as Assistant Lecturers in 1978 (1), 1988 (1), 1992 (1), 1996 (1), 1997 (2), 1998 (1), 1999 (2), 2000 (1), 2001 (1) and 2003 (2).

They had left for their postgraduate studies (11), to accompany the spouse who had gone for postgraduate studies (3), on sabbatical leave (1) and on a research contract (1). Twenty-one had obtained research scholarships (six from foreign universities, two from the Asian Development Bank, one each from the World Bank and the Japanese Government). Four respondents stated that they had not received any scholarship.

All academics had completed their Ph.D's. They had resigned from the universities in 1996 (2), 2001(3), 2002(1), 2003(1), 2004 (1), 2005(1), 2006(1), 2008(1), 
Table 4: Reasons for migrating overseas (multiple responses)

\begin{tabular}{llrr}
\hline No. & Reason & No. & $\%$ \\
\hline 1 & Conditions in the country were not conducive & 10 & 24.4 \\
2 & Conditions in the university/Dept. was not conducive & 8 & 19.5 \\
3 & Prospects overseas were attractive & 6 & 14.6 \\
4 & Educational facilities for my children were better & 6 & 14.6 \\
5 & Non-availability of study leave & 2 & 04.9 \\
6 & Lack of a peer community interested in the particular field of research & 2 & 4.9 \\
7 & Lack of opportunities to engage in research & 2 & 04.9 \\
8 & Bureaucratic procedures & 1 & 02.4 \\
9 & My spouse obtained a university position & 1 & 02.4 \\
10 & My spouse is a foreign citizen & 1 & 02.4 \\
11 & Served with vacation of post & 1 & 02.4 \\
& No response & Total & 1 \\
\hline
\end{tabular}

2009) (2), in 2010 (2), 2011(1) and in 2012 (1). One respondent explained how he had obtained leave for three years to assume duties as a Vice-Chancellor of a university but had not been allowed to assume duties. "After three years, I was served with vacation of post" he stated.

Accoding to Table 4, the reasons given by the academics for deciding to migrate overseas were as follows:

It is significant that the highest number $(24.4 \%)$ had stated that the decision to migrate was due to the nonconducive situation in the country (probably due to the conflict situation that prevailed at the time), followed closely by conditions in the university/department being not conducive (19.5\%). A total of $29.2 \%$ (when the six who spoke of better educational facilities for children overseas are included) had affirmed that prospects overseas were attractive.

Some of their experiences are portrayed vividly in the following excerpts.

\section{Non-conducive conditions in the country}

1) "The income was not enough to live a decent life in Sri Lanka. Finding additional sources of income was not a choice, but a must. This did not leave any time for research."

2) "In Sri Lanka, those who go behind politicians get their work done. No place for educated people. Politics in university management is also the same."

\section{Non-conducive conditions in the University/ Department}

1) "Even simple things, they don't want to do."

2) "The Dept. in the University where I worked was not a nice place to work in. It seems to be a place with no future. I am so glad that I have got out. I would have never left Sri Lanka if this was not the case."

3) "Top administrative jobs in university system are based on internal and external politics, not vision and capabilities."

\section{Better prospects overseas}

1) "In particular, there are no possibilities of transfer in Sri Lankan Universities. Moving across universities /jobs is very flexible in other countries."

2) "I think I enjoy freedom, initiatives, facilities, and appreciation when I do something innovative and changing the way of doing things."

\section{Better educational facilities for children}

1) "If I had comeback, I would have had severe problems putting my children to a good school in Colombo or Kandy. Instead of teaching my preschool kid 'how to cheat the Grade 1 selection panel', I chose to migrate."

2) "Easier life for children (education not as competitive as in Sri Lanka)." 
3) "I was able to provide the education for my children from my earnings and contributions from the Institute where I worked. They completed education in a time-bound manner. No strikes, no delays in academic programmes, no tuition outside school. Children enjoyed education. Teachers taught and guided them and they played after school \& became independent. As a father, I preferred that."

\section{Lack of opportunities to engage in research (including international research)}

1) "Isolation from the international research community. I tried to minimize this by organizing an international conference in Sri Lanka but attending leading conferences outside Sri Lanka was a mission."

2) "It was extremely difficult to purchase components needed to do robotics research. The system needed three quotations even for computers, motors, ICs, etc. And it was a nightmare to clear these items from Customs. This slowed down my work significantly."

3) "I tried to make some contribution to humanitarian landmine detection, but the struggle was too much. There was only one national institution providing systematic funding for research."

\section{Bureaucratic procedures}

1) "Apart from the financial constraints, having to take permission from the country's Prime Minister to attend a simple meeting abroad was ridiculous."

2) "University administration is more on rules and regulations rather than working towards future and opportunities."

\section{Family commitments}

"My spouse did not have attractive employment prospects in Sri Lanka. Therefore I had to resign and migrate, which helped me to complete my Ph.D. as I did not have sufficient funds from the ADB."

\section{Decision to leave after returning to Sri Lanka}

Three of the academics had returned to Sri Lanka after completing their postgraduate studies: two of them after five years and the other after four years, but had decided to migrate. They gave the following reasons for deciding to leave even after returning.
1) "After coming back with the $\mathrm{PhD}$, I wanted to do some improvement to the Department but Heads (especially) and other higher authorities at that time (some, not all) were not supportive and totally created a demotivating situation."

2) "We went back to Sri Lanka as we wanted to work and make a difference to our higher education, research and industry; we did a few of them with a lot of struggle and difficulties as our university systems and processes including situation of the country did not provide support to carry on good work and make changes. There is no system to compensate/remunerate/recognize excellent contributions to learning, teaching, research, and community engagement in our higher education system; no performance based appreciation and promotions."

3) "As I am a very dedicated person for my work and the university, I felt that university wasn't performing as it could be. The University has plenty of potential but I feel that we exploit just less than $50 \%$ of them. I worked in several academic administrative positions and represented higher level academic and administrative forums and meetings. To get all to work is very difficult and a plenty of negativity and very few want make a difference."

4) "Plenty of internal politics and they don't want to get help from qualified and capable academics, they just want to hire and work with junior staff that department thinks easy to continue its leadership."

The respondents were asked whether migration had helped them to realise their expectations. Overall, the responses were positive:

\section{Realisation of expectations after migration}

1) "Migration helped me to achieve several things in my life. Not only the Ph.D., but I also have got exposed to the international research culture and developed a professional career. Most attractive part is that the jobs overseas mostly reward performance unlike the number of years in service in Sri Lanka."

2) "Yes, I work for a well-respected organization with dignity and my child is having a good education away from the rat race in Sri Lanka."

3) "We served at the top of the University and a few other national institutions but we cannot get a 
placement for our children in good schools: those who go behind politicians get them done. All the other things are the same. No place for educated people. Politics in university management was also the same."

4) "Both my wife and I are employed in fulltime positions and enjoy very supporting workplaces where people are open to new ideas. The ability to go up the ladder by merely working hard (but not because of getting old) is very motivating and we are continuously achieving rewards of this system."

5) "I obtained a tenured position in one of the Australian Universities soon after I completed my postgraduate studies. Career opportunities were the main reasons for me to migrate. Migration helped me develop my research trajectory and participate in research activities on an international level."

6) "After migrating to US, the experience at Harvard and MIT universities was memorable. They led to live collaborations, intellectual stimulation, and freedom of exploration. The monthly pay was enough to live, there was freedom of expression, no fear of death due to political views, strong rule of law gave comfort to the family and children, and the justice system we experienced in various difficult situations was apparently fair. Above all, there was no need to be known to politicians or influential people to send our children to decent schools, or to obtain some Government positions. There was a system."

\section{Efforts to support Sri Lanka after migration}

A few described their efforts to support Sri Lanka even after migration.

1) "I sought to support by training individuals from Sri Lanka, support them to become researchers and scientists to work in academia and industry, helping undergraduates who need financial assistance in the Faculty I studied and worked. I have become an extended part of the Sri Lankan society and the professionals."

2) "I didn't personally want to resign from my position, but situation and circumstances forced me to do so. While I am enjoying work and engagement in developed country university systems and processes, I want to help Sri Lankan university and industry with my skills and experience over last 25 years. If I get an opportunity to do so at least during my annual leave and sabbatical leave period, I am more than happy to come and serve. Still I have that desire."

3) "Throughout the past decade I have contributed to SL from outside by establishing official collaborative links between my work places (in Japan) and University of Peradeniya and providing scholarships to Sri Lanka students to do their higher studies in Japan, exchanging senior researchers and carrying out collaborative research with Sri Lankan researchers etc. Therefore, I believe that I may have contributed more than some of the academics who returned to Sri Lanka at the end of the compulsory bond period."

\section{Mixed Feelings}

A few had mixed feelings.

1) "Mixed feelings. I am not fully happy about the migration decision. Even though working conditions and economic benefits are better, socio-psychological satisfaction is not there."

2) "No big expectation as there were no big plans. Migration helped to live a peaceful life (sometimes lonely though), more flexibility in career, easier life for children (education not as competitive as in Sri Lanka), travel to other countries (hobby) and generally living a more comfortable life."

3) "Within the last ten years, I believe I gained what I went abroad for: the opportunity to be exposed to the international community of scholars and gather knowledge and experience in diverse disciplines at the standards of the countries in the forefront in those fields. Though I love my country very much, I would not have been able to learn at this level within the country."

\section{Innovative strategies introduced}

One academic explained at length how his attempts to put into action innovative strategies had been received.

1) "I served as the Commissioner of the Sri Lanka .... Commission as a Steering Committee member of the Centre for Research and Development, Ministry of ...., and a member of the Board of Governors of the .... Centre. Some achievements were memorable. But the system was geared to punish mistakes than reward achievements. Soon before resigning from the Inventors' Commission, I was asked to submit explanations as to why the cost/employee had increased 15 times during my time. It took me a lot of time to explain that in 
a research funding institute, the cost/employee increases when the funding level and funding sources increase if total grants awarded from the Institute are taken as costs incurred by the institute."

2) "In another case, I tried to promote food innovation in Sri Lanka by declaring a grand challenge among housewives to come up with a dish made of bitter gourd. In order to promote this among most of the estimated 5million housewives in Sri Lanka, I declared an award of Rs. 500,000 for the best dish that would be selected by a panel of children under 14 years of age.

My expectation was that this lucrative award will make these housewives spend at least Rs. 100 on various trials. This would mean Rs. 50 million of economic activity in addition to a widespread effort to innovate novel ways to cook rural vegetables if promoted properly. I ended up in a hearing at the President's Palace. It was a frustrating experience to explain the grand goals of this effort."

Another academic explained that he resigned because of the wrong treatment meted out by the University and Courts by deleting his qualifications and compared it with the favourable and pleasant environment abroad, and receiving encouragement from administration \& colleagues to get new knowledge, support for professional development.

\section{Regrets about migration}

Others, who had regrets about the decision to migrate, shared them with us.

1) "I always feel that I miss my people and that I can do more to change our social order and peoples' lives as we do here for someone (certainly they look after us, if we do a good job), but when I think back, it is scary to think how difficult it is to work in Sri Lankan universities as they are full of politics and negativity among the academic and non-academic community. I am a strong believer that we can change Sri Lankan university system with a steady and positive approach by liberating academics from politics and find leaders who combine vision with action."

2) "Inability to serve the country I grew up in, is the main regret I have. However, I am determined to pay back what my country spent on my education."

3) "If the country and the university system are good, we might come back. It should be done not by words but by deed. No cunning invitations are required to come back. People are watching if genuine efforts are being made and results can be seen."

4) "There are pros and cons in migration. My children missed the opportunity of being raised in the country and culture which they have inherited from thousands of generations, but at the same time they have endless opportunities here for their future. Of course their level of Sinhala language is not at par with the same age kids who grewup in Sri Lanka, but I am sure their knowledge on Buddhism is comparable or better. However, I always have concerns about their relationships with extended family living in Sri Lanka in the future."

5) "From my side as an academic I always would like to comeback to Sri Lanka and work, but cannot do it until my kids finish their education."

6) "I always feel I want to do something more to our students in Sri Lanka as I always want to do it for my country."

7) "My only regret is that Sri Lanka does not still have in place an effective system to tap into the kind of expertise that I can offer."

8) "I was forced to migrate. I wanted to teach what I knew having learned under a Nobel Laureate and doing State of the Art research at big universities but was not given the opportunity."

9) "Leaving the University of Peradeniya was my only regret."

10) "The most regrettable part is with the immediate and the extended family."

11) "But Sri Lanka is home and where my parents, relatives and some of my friends are. I do miss them and where I grew up. That's one place where I would like to work if there were good conditions for that."

12) "Primary and secondary education in Sri Lanka is much better and more competitive. Raising children with our cultural values and other positive attributes are much harder in some foreign environments."

A total 13 academics said, they had no regrets at all about the decision to migrate. One in fact, said,

"I have no regrets whatsoever in regards to my decision. It has certainly been the best decision I have ever made and an investment in my life." 
Yet some of them were appreciative of the institutions which they had worked closely with.

"I have no regrets at all. However, NSF funded my work in Sri Lanka. For that, I want to continue organizing international conferences in Sri Lanka and maintain collaborative research."

One was hopeful that if the country and the university system is good, "we might come. It should be good by deed and not by words".

Some were quite blunt:

1) "If you want to avoid Brain Drain in Sri Lanka, you need to change the whole political culture of impunity and stupidity."

2) "I don't have any regrets on my decision since the people who work there are making all the others leave."

\section{Suggestions on changing the existing system}

Some had suggestions on how the existing system could be changed.

1) "We would be able to introduce a result-oriented remuneration system and include learning, teaching, research and community engagement as performance indicators to measure and monitor university performance from individual to university as a whole.

Our universities even don't bother keeping contacts with the academics who have migrated and professionals to get their input and support to develop university systems and capabilities. Simply they can help at a distance as well as they can come and help even when they come for holidays/vacations, and on their sabbatical leave. It is about creating relationships and developing collaboration."

2) "If someone in Sri Lanka could coordinate with us and arrange opportunities for us so that we could serve our country in our fields (like teach courses, workshops) during our vacation months here, we would love it."

\section{CONCLUSIONS AND RECOMMENDATIONS}

The analysis of the information provided by the universities was scanty and mostly incomplete. What is pertinent to note is that, despite the costs of supporting postgraduate education of the academics, in addition to providing them with full-pay study leave in most cases, some have not returned to resume their work. The majority had paid back their bonds. As pointed out, the loss is not only financial but has a deeper impact on the future improvement of the quality of university education. Those who responded to the survey clearly indicated that the majority of them are experienced in their specialised areas, had benefitted from postgraduate education and international research in eminent universities, are articulate, creative and willing to take challenges; a category of academics that can definitely make a contribution to the university system. Obviously, the scenario depicted is one of Brain Drain not of Brain Gain.

The few academics who responded to the survey, provided useful insights to the circumstances that impelled them to migrate. It was clear that all of them had found the situation in the countries to which they had migrated to, to be attractive for work, with rewards and recognition, better economic benefits and opportunities for children's education in comparison with Sri Lanka. Poignant, however, were their descriptions of a lack of vision of the top Sri Lankan administrators, mostly at university level, a lack of commitment on the part of other staff, less priority being given to research with bureaucratic procedures given more emphasis in Sri Lanka. Their responses regarding the attempts made to innovate and make a change, was sufficient evidence that they could have indeed infused talent and creativity and provided leadership to a system which is fast becoming 'headless' and 'leaderless'.

It is pertinent to note here that Sri Lanka ranks in Higher Education and Training listed under Efficiency Enhancers in the Global Competitiveness Index (World Economic Forum, 2014-15) at 73, (as compared to 79 in 2012-13) second among South Asian countries, but below some South-East Asian countries: Malaysia (20), Thailand (31), Indonesia (34) and Philippines (52). In Innovation and Sophistication Factors, Sri Lanka's rank is 43, again the best in South Asia.

It is also relevant to note however, that in 2015 University Rankings (Times Higher Education), University of Colombo which ranked highest among Sri Lankan universities occupied the World Rank of 2034 with an Impact Rank of 3736. Rankings of other state Universities are Peradeniya (2225), Moratuwa (2401), Kelaniya (3120), Sri Jayewardenepura (4268), Ruhuna (4511), Wayamba (5038), Open University (5557), Jaffna (6549), Rajarata (9694), South-Eastern $(10,016)$, Sabaragamuwa $(10,989)$, Eastern $(11,252)$, Visual and Performing Arts $(14,052)$ and Uwa-Wellassa $(15,702)$. It is clear that our universities have a long way to go to attain the status of world class universities. 
Thus, the challenges to overcome the adverse consequences of the Brain Drain cannot be underestimated. On the one hand, the country has invested much from state funds as well as donor funds on developing these academics for the future strengthening of our university system. Yet, as the academics who had migrated point out, the decision to migrate is not merely an outcome of attractive prospects overseas, but also due to frustrations and difficulties encountered in changing even minor procedures, a lack of collegiality and teamwork and a lack of readiness to adapt and change in the country and the university system.

Even though a complete overhaul of the existing system may not be feasible, it is therefore, opportune for the higher education authorities to devote attention to consider feasible strategies such as removal of bureaucratic procedures, putting in place equitable and objective rewards schemes, developing a collegial atmosphere in university Departments and Faculties, elimination of political nepotism and attempt to reverse the Brain Drain to Brain Gain by working collaboratively with migrant academics, who are willing to work with Sri Lankan universities.

\section{REFERENCES}

Adams, R. H. Jr., (2003) International migration, Remittances and the Brain Drain: A Study of 24 Labour Exporting Countries, World Bank.

Awasthi, S. P. and Chandra, A. (1994) Migration from India to Australia, Asian and Pacific Migration Journal, 3(2-3), pp: 393-409.

DOI: https://doi.org/10.1177/011719689400300207

Beine, M., Docquier, F. and Rapoport, H. (2001) Brain drain and economic growth: theory and evidence, Journal of Development Economics, 64, pp: 275-289.

DOI: https://doi.org/10.1016/S0304-3878(00)00133-4

Bernstein, J. H. and Shuval, J. T. (1995) Occupational continuity and change among immigrant physicians from former Soviet Union in Israel, International Migration, 33, pp: 3-29.

DOI: https://doi.org/10.1111/j.1468-2435.1995.tb00017.x

Castanos-Lomnitz, H. (1998) The brain drain from Mexico: the experience of scientists, Science and Public Policy, 25(4), pp: $247-253$.

Chau, N. and Stark, O. (1999) Migration under Asymmetric Information and Human Capital Formation, Review of International Economics, 7 (3), pp: 455-83.

DOI: https://doi.org/10.1111/1467-9396.00175
Commander, S., Chanda, R., Kangasniemi, M. and Winters, A. (2008) The Consequences of Globalisation: India's Software Industry and Cross-Border Labour Mobility, The World Economy, 31 (2), pp: 187-211.

DOI: https://doi.org/10.1111/j.1467-9701.2007.01071.x

Constant, A. and Massey, D. (2002) Return Migration by German Guest workers: Neoclassical versus New Economic Theories, International Migration, 40 (4), pp: 5-38.

DOI: https://doi.org/10.1111/1468-2435.00204

Dustmann, C. and Weiss, Y. (2007) Return Migration: Theory and Empirical Evidence from the U.K., British Journal of Industrial Relations, 45 (2), pp: 236-256.

DOI: https://doi.org/10.1111/j.1467-8543.2007.00613.x

Galor, O. and Tsiddon, D. (1997) The distribution of human capital and economic growth, Journal of Economic Growth, 2(1), pp: 93-124.

DOI: https://doi.org/10.1023/A:1009785714248

Global Commission on International Migration (2005) Migration in an Interconnected World: New Directions for Action [Online] Available from: https://www.unitar.org/ny/ sites/unitar.org.ny/files [Accessed: $20^{\text {th }}$ August 2015].

Gundel, S. and Peters, S. (2008) What Determines the Duration of Stay of Immigrants in Germany? Evidence from a Longitudinal Duration Analysis, International Journal of Social Economics, 35(11), pp: 769-782.

DOI: https://doi.org/10.1108/03068290810905414

Haque, N. U. and Kim, S. J. (1995) Human Capital Flight: Impact of Migration on Income and Growth, Staff Papers, International Monetary Fund [Online] Available from: http:// www.jstor.org.stable/3867533 [Accessed: $22^{\text {nd }}$ August 2015].

Haque, N. U. (2007) Brain Drain or Human Capital Flight, Lectures in Development Economics, 11 [Online] Available from: https://papers.ssrn.com/sol3/papers.cfm?abstract_ id $=987449$ [Accessed: 22 ${ }^{\text {nd }}$ August 2015].

Hawthorne, L. (1997) The question of discrimination: skilled migrants' access to Australian employment, International Migration, 35(3), pp: 395-419.

DOI: https://doi.org/10.1111/1468-2435.00019

Iredale, R. (1999a) The need to import skilled personnel: factors favouring and hindering its international mobility, International Migration, 37(1), pp: 89-123.

DOI: https://doi.org/10.1111/1468-2435.00067

Iredale, R. (199b) Barriers to migrant entry to occupations in Australia, International Migration, 27(1), pp: 87-108.

DOI: https://doi.org/10.1111/j.1468-2435.1989.tb00348.x 
Lovell, B. L. (2001) Policy Responses to the International Migration of Skilled Labour, 45 International Migration Papers, International Migration Branch, ILO Geneva [Online] Available from: http:/www.ilo.org/wcmsp5/groups/pub;lic [Accessed: 22 ${ }^{\text {nd }}$ August 2015].

Luo, Y. L. and W. J. Wang (2002) High-skilled Migration and Chinese Taipei's Industrial Development, International Mobility of the Highly Skilled, OECD, Paris, pp: 253- 269 [Online] Available from: http://pesona.mmu.edu.my/ chtan/ Seminar/9202011E.pdf [Accessed: 22 ${ }^{\text {nd }}$ August 2015].

Mayr, K. and Peri, G. (2009) Brain Drain and Brain Return: Theory and Application to Eastern-Western Europe, Working Paper No. 0919, Labor and Welfare State, Linz: The Austrian Center for Labor Economics and the Analysis of the Welfare State.

McCormick, B. and Wahba, J. (2001) Overseas Work Experience, Savings and Entrepreneurship Amongst Return Migrants to LDC's, ScottishJournalofPoliticalEconomy, 28(2),pp: 164-178 [Online] Available from: http://citeseerx.ist.psu.edu/viewdoc/ download?doi=10.1.1.584.5015\&rep=rep $1 \&$ type $=$ pdf [Accessed: 22 ${ }^{\text {nd }}$ August 2015].

Miyagiwa, K. (1991) Scale Economies in Education and the Brain Drain Problem, International Economic Review, 32 (3), pp: 743-759.

DOI: https://doi.org/10.2307/2527117

Mountford, A. (1997) Can a brain drain be good for growth in the source economy?, Journal of Development Economics, 53 (2), pp: 287-303.

DOI: https://doi.org/10.1016/S0304-3878(97)00021-7

National Centre for Advanced Studies in Humanities and Social Science (2014) Annual Research Symposium- 2014.

Papademetriou, D. G. and Yale-Loehr, S.(1996) Balancing Interests: Rethinking U.S. Selection of Skilled Immigrants, Washington, Washington: Carnegie Endowment for International Peace [Online] Available from: http://files.eric. ed.gov/fulltext/ED406482.pdf [Accessed: 22 ${ }^{\text {nd }}$ August 2015].

Rapoport, H. (2002) Who is afraid of the brain drain? Human capital flight and growth in developing countries, Stanford: Stanford University [Online] Available from: http://www-siepr. stanford.edu/Papers/briefs/policybrief_apr02.pdf [Accessed: $14^{\text {th }}$ July 2015].

Rhode B. (1993) Brain drain, brain gain and brain waste : reflection on the emigration of educated and scientific personnel from Eastern Europe, In R. King (ed.) The New Geography of European Migration, pp: 228-245, Paris: OECD.

Robinson V. and Carey M. (2000) Peopling Skilled International Migration: Indian Doctors in the UK, International Migration, 38 (1), pp: 89-108.

DOI: https://doi.org/10.1111/1468-2435.00100

Salt, J. (1983) High level manpower movements in Northwest Europe, International Migration, 17, pp: 633-652.

DOI: https://doi.org/10.2307/2545822

Salt, J. (1997) International Movements of the Highly Skilled, OECD Social, Employment and Migration Working Papers, No. 3, Paris: OECD Publishing.

Schiff, M. and Wang, Y. (2008) Brain Drain and productivity Growth: Are Small States Different?, Discussion Paper No. 3378, Bonn: IZA Institute of Labor Economics [Online] Available from: http://ftp.iza.org/dp3378.pdf [Accessed: $22^{\text {nd }}$ August 2015].

Schwab, K. (ed.) Global Competitiveness Report 2014 - 2015, Geneva: World Economic Forum [Online] Available from: http://www3.weforum.org/docs/WEF GlobalCompetitivenessReport 2014-15.pdf $\quad$ [Accessed: $22^{\text {nd }}$ August 2015].

Skeldon, R. (1992) International migration within and from the East and Southeast Asian Region: an essay, Asian and Pacific Migration Journal, 1(1), pp: 1-22.

DOI: https://doi.org/10.1177/011719689200100103

Teng, Y. M. (1994) Brain drain or links to the World: views on emigrants from Singapore, Asian and Pacific Migration Journal, 3 (2-3), pp: 411-429.

DOI: https://doi.org/10.1177/011719689400300208

Times Higher Education (2015) World University Rankings [Online] Available from: https://www.timeshighereducation. $\mathrm{com} / \mathrm{se}$ arch $\mathrm{e}=404 \& \mathrm{se}$ ar ch $=$ new s $\% 20 \mathrm{w}$ or $1 \mathrm{~d} \% 20$ university\%20rankings [Accessed: 22 ${ }^{\text {nd }}$ August 2015].

World Bank (2009) The Towers of Learning: Performance, Peril and Promise of Higher Education in Sri Lanka, Washington D.C.: World Bank.

World Bank (2011) Migration and Remittances Fact Book 2011 [Online] Available from: https://siteresources.worldbank.org/ INTLAC/Resources/Factbook2011-Ebook.pdf [Accessed: $20^{\text {th }}$ August 2015]. 


\section{APPENDIX}

Questionnaire to Vice-Chancellor

1. Name and address/email address of the staff member

2. The Department to which he/she was attached

3. Whether leave was granted

4. Whether a scholarship had been approved

5. If Yes, the total grant of the Scholarship

6. When the academic resigned from the University 